\title{
Innovative processes and modernization in the agroindustrial complex of the Russian Federation: results and prospects
}

\author{
Ekaterina Letyagina ${ }^{1, *}$, Anna Storozheva ${ }^{1}$, and Elena Dadayan ${ }^{1}$ \\ ${ }^{1}$ Krasnoyarsk State Agrarian University, Krasnoyarsk, Russia
}

\begin{abstract}
This article outlines the results of the study of innovative processes and modernization of the agroindustrial complex in the Russian Federation, determined by Russia joining the World Trade Organization, strengthening of the food crisis, and other worldwide processes. We have considered and analyzed the facts and features determining innovation and modernization tendencies of agroindustrial production in the Russian Federation, and revealed the problems occurring during introduction of innovations and various knowledge-intensive designs. In addition, we considered the possibilities for modernization of the agroindustrial complex depending on the type of agricultural activity, and outlined possible ways of overcoming the difficulties over the course of innovative processes and the modernization of Russian agriculture, taking into account modern sociopolitical and economic realities and requirements. At the same time, the study provides an analysis of statistical data that clearly substantiate the state of modern agriculture in the Russian Federation and the prospects for its development. Moreover, the article reflects the issues of the formation and implementation of the state policy in innovation and modernization, highlights its main approaches and objectives, the implementation of which will allow avoiding the impact of the global food crisis and ensuring the food security of the Russian Federation.
\end{abstract}

\section{Introduction}

The relevance of the study is determined by the current situation, which, given the significant population growth rate, leads to a growing demand for food, and, as a result, predetermines the urgent need to improve the efficiency of agricultural production, which should ultimately lead to a reduction in production costs and to provision for full nutritional needs of the society as a whole. Many researchers focusing on this problem share this viewpoint [1].

The food crisis, the rate of development of which varies in different countries, now affects almost all the states [2]. Even if the country does not have a pressing food shortage, no nation in the world can afford to ignore the global trends of resource base reduction, its depletion and restructuring.

In the long term, given the increase in quality of life and healthcare, the average life expectancy of a person will undoubtedly increase, which, of course, will lead to an increase in the world's population, both in general and in individual countries.

Therefore, considering the above trends, it is necessary to improve the efficiency and productivity of agricultural industry, which, with a reduction in the capacity and space used, not only will maintain the volume of food production, but also increase it.

Meanwhile, it should be noted that agricultural producers should not ignore the global trends of digitalization and informatization, which define today not only production processes, but also the system of management of the agricultural industry [3].

\section{Purpose of the study}

The main purpose of our study is to determine the innovative processes and modernization of the agroindustrial complex of the Russian Federation, its results and prospects for further modernization of agricultural production.

\section{Research problems}

The research will provide answers to the following problems:

1. Which factors and features determine innovative processes in the agroindustrial production of the Russian Federation?

2. What are the key innovation trends in agriculture of the Russian Federation?

3. Which problems and challenges do agricultural producers face during modernization and improvement of the production processes?

4. What are the results and prospects for innovation and modernization in the agricultural production of the Russian Federation?

\footnotetext{
* Corresponding author: let_k@mail.ru
} 


\section{Research methods}

The research methods used in our study are:

- theoretical (analysis of scientific literature, etc.);

- empirical (analysis of data and indicators of agricultural production in dynamics, etc.).

\section{Results and discussion}

The main goal of agricultural modernization, in our opinion, is to increase its efficiency and productivity by increasing the knowledge intensity of the production process [4]. The solution to this problem will allow the Russian Federation to overcome the food crisis, to maintain the balance between the demand for agricultural products and their supply, as well as to increase the competitiveness of Russian products in the world food market.

The importance of increasing the pace of innovation and knowledge intensity is confirmed by the data of selfsufficiency in food in the Russian Federation, presented in Table 1.

Table 1. Levels of self-sufficiency in basic foods, $\%$.

\begin{tabular}{|c|l|c|c|c|c|c|}
\hline \multirow{2}{*}{ No. } & \multirow{2}{*}{ Food } & \multicolumn{5}{|c|}{ Year } \\
\cline { 3 - 7 } & & $\mathbf{2 0 1 4}$ & $\mathbf{2 0 1 5}$ & $\mathbf{2 0 1 6}$ & $\mathbf{2 0 1 7}$ & $\mathbf{2 0 1 8}$ \\
\hline 1. & Grain & 153.8 & 149.1 & 160.0 & 170.6 & 174.2 \\
\hline 2. & Meat & 82.8 & 88.7 & 90.6 & 93.5 & 95.7 \\
\hline 3. & Milk & 78.1 & 79.9 & 80.7 & 82.3 & 83.9 \\
\hline 4. & Eggs & 97.6 & 98.2 & 98.6 & 98.9 & 95.8 \\
\hline 5. & Potatoes & 98.0 & 102.1 & 93.2 & 91.1 & 95.3 \\
\hline 6. & $\begin{array}{l}\text { Vegetables } \\
\text { and edible } \\
\text { melons }\end{array}$ & 84.1 & 86.8 & 87.4 & 87.6 & 87.2 \\
\hline 7. & $\begin{array}{l}\text { Fruits and } \\
\text { berries }\end{array}$ & 32.5 & 32.5 & 36.5 & 33.1 & 38.8 \\
\hline
\end{tabular}

From these data it is clear that the level of selfsufficiency in basic foods reaches and exceeds 100\% only for grain. All other basic foods are not provided fully $(100 \%)$ by Russian agricultural producers, moreover, the level of supply of milk, vegetables, edible melons, fruits and berries does not even reach $90 \%$.

At the same time, analyzing the annual growth rate of self-sufficiency, we can state that it is not high. More than that, among foodstuffs such as eggs, milk, vegetables and edible melons, the growth rate of indicators was less than $0.5 \%$, which cannot be considered sufficient.

In general, we should also note that innovative, knowledge-intensive modernization processes in the agroindustrial complex have their own specifics. The most common classification of agricultural innovations is by the manufacturing sectors [5]. In this manner, we can identify as knowledge-intensive: innovations in the economic field of agriculture; innovations in the organization and management of the agroindustrial complex; innovations in the agricultural and plant industries; innovations in livestock and veterinary medicine; modernization in the mechanization and automation of agriculture; innovations in the storage and processing of agricultural products.
We should note here that in the economic sphere of agricultural production, management, and organization it is necessary to introduce such innovations as new modernized knowledge-intensive enterprises, as well as to employ new methods and ways of managing agricultural production using innovative forms of motivation and control of labor, etc.

In addition, in previous studies, we have covered the specifics of financial recovery and bankruptcy procedures of agricultural enterprises, which also define innovative processes and allow modernizing agricultural enterprises, ensuring their functioning in a competitive market environment [6]. We believe that in the financial recovery of agricultural enterprises it is necessary to take into account the main characteristics of agricultural production, such as highly labor-intensive processes, remoteness from direct markets for manufactured products, low profitability, and introduce innovations reducing the impact of these negative factors hindering the development of agricultural production.

We believe that innovations in the area of power capacity per worker, its growth in agricultural organizations, would have a positive impact on improving the profitability and productivity of agricultural enterprises.

In general, according to Figure 1, this indicator in the Russian Federation is growing, although we believe that its growth rate is insufficient to indicate a high rate of modernization of agricultural enterprises.

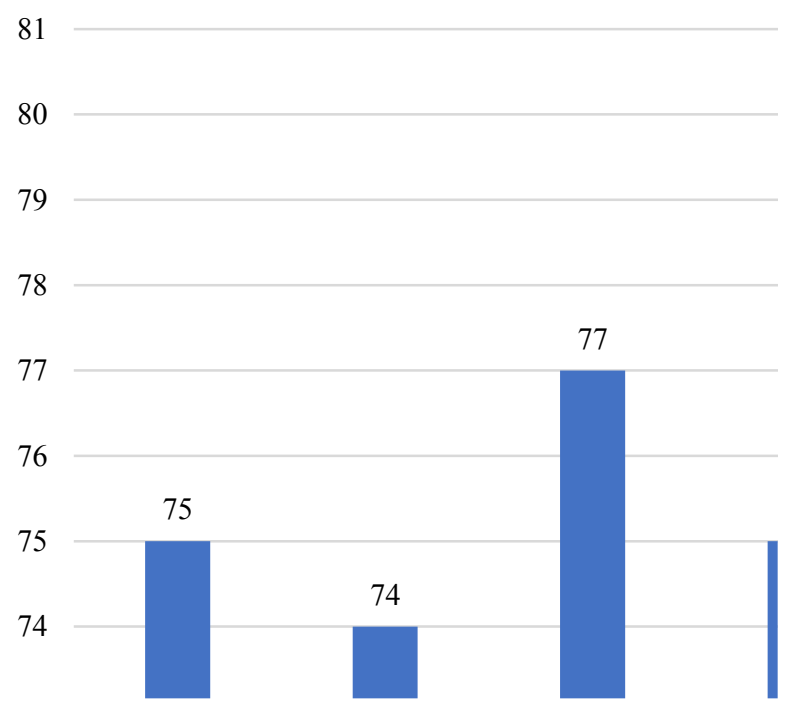

Fig. 1. Power capacity per worker in agricultural enterprises.

We should also mention that this indicator is directly dependent on the modernization, systematic improvement and renewal of agricultural machinery, which is used by agricultural producers. What improves the efficiency and profitability of agricultural enterprises is the increase in automation of agricultural processes through the use of high-tech agricultural equipment [4].

We can observe a decline in the growth rate of production of key types of agricultural machinery, with the exception of potato harvesting and primary processing equipment (Table 2). 
Table 2. Production of basic agricultural machinery, thousands of units.

\begin{tabular}{|c|l|c|c|c|}
\hline \multirow{2}{*}{ No. } & Type of agricultural & \multicolumn{3}{|c|}{ Year } \\
\cline { 3 - 5 } machinery & $\mathbf{2 0 1 6}$ & $\mathbf{2 0 1 7}$ & $\mathbf{2 0 1 8}$ \\
\hline 1. & Tractors for agriculture & 6.3 & 7.3 & 7.1 \\
\hline 2. & $\begin{array}{l}\text { General purpose } \\
\text { ploughs }\end{array}$ & 7.9 & 21.0 & 19.7 \\
\hline 3. & Cultivators & 50.8 & 49.5 & 35.4 \\
\hline 4. & Rippers & 4.1 & 6.4 & 4.2 \\
\hline 5. & Sowing machines & 6.8 & 6.2 & 6.7 \\
\hline 6. & $\begin{array}{l}\text { Agricultural machinery } \\
\text { for soil processing }\end{array}$ & 4.2 & 12.8 & 5.9 \\
\hline 7. & Mowers & 6.8 & 6.8 & 5.7 \\
\hline 8 & $\begin{array}{l}\text { Machines for harvesting } \\
\text { and primary potato } \\
\text { processing }\end{array}$ & 180 & 881 & 935 \\
\hline 9. & Grain harvesters & 6.1 & 7.6 & 4.6 \\
\hline 10. & $\begin{array}{l}\text { Pickers for grains, } \\
\text { oilseeds, legumes, and } \\
\text { cereals }\end{array}$ & 446 & 289 & 125 \\
\hline 11. & $\begin{array}{l}\text { Machines for harvesting } \\
\text { grains, oilseeds, } \\
\text { legumes, and cereals }\end{array}$ & 13.6 & 14.1 & 11.9 \\
\hline 12. & $\begin{array}{l}\text { Machines for harvesting } \\
\text { and primary corn } \\
\text { processing }\end{array}$ & 183 & 200 & 47 \\
\hline 13. & Milking plants & 3.8 & 3.9 & 3.3 \\
\hline 14. & Poultry incubators & 7.6 & 5.7 & 1.1 \\
\hline
\end{tabular}

We should note the high importance for innovative processes and modernization of agricultural production of the annual volume of investment in fixed capital, which is a combination of material investments in construction and reconstruction of agricultural production facilities [7]. The listed investments lead to an increase in their initial cost. Additionally, investments in fixed assets include the cost of purchasing equipment, transport, and agricultural machinery. Moreover, investment in knowledge-intensive intellectual property, including scientific developments and patents, etc., is currently an important component of investment in fixed capital. Here we can state that in the Russian Federation since 2015 there has been an increase in investment activity in fixed assets, however, this percentage is low in the total investment numbers and tends to decline, as Table 3 demonstrates.

Table 3. Investments in fixed capital aimed at agricultural development.

\begin{tabular}{|l|c|c|c|c|}
\hline & 2015 & $\mathbf{2 0 1 6}$ & $\mathbf{2 0 1 7}$ & $\mathbf{2 0 1 8}$ \\
\hline $\begin{array}{l}\text { Investments in fixed } \\
\text { capital } \\
\text { operating prices), billion } \\
\text { rubles }\end{array}$ & 304.7 & 379.5 & 400.5 & 431.8 \\
\hline $\begin{array}{l}\text { Investment in fixed } \\
\text { capital as a percentage of } \\
\text { total investment }\end{array}$ & 2.9 & 3.4 & 3.3 & 3.2 \\
\hline
\end{tabular}

We should also note that in general, modernization and innovative processes in agriculture are aimed at increasing the yield and quality of crops, increasing the productivity of animals and birds, introducing new tools for the growth and protection of plants, increasing soil fertility, mechanization and automation of the technological processes in the agroindustrial complex.

We need to mention that the pace of innovative processes and modernization of agriculture in the Russian Federation in recent years, due, among other things, to Russia joining the World Trade Organization [10] and to the increase in demand for domestic agricultural products owing to economic sanctions against Russia, has decreased slightly. This situation is evident in the decline in the values of the key performance indicators of agricultural organizations listed in Table 4 and is caused by a decline in the overall rate of economic growth in the Russian Federation.

Table 4. Key performance indicators of agricultural enterprises.

\begin{tabular}{|l|l|c|c|c|c|c|}
\hline No. & & $\mathbf{2 0 1 4}$ & $\mathbf{2 0 1 5}$ & $\mathbf{2 0 1 6}$ & $\mathbf{2 0 1 7}$ & $\mathbf{2 0 1 8}$ \\
\hline 1. & $\begin{array}{l}\text { Sowing area, million } \\
\text { hectares }\end{array}$ & 55.3 & 55.1 & 54.7 & 54.4 & 53.6 \\
\hline 2. & $\begin{array}{l}\text { Livestock and poultry } \\
\text { headcount at the end of } \\
\text { the year, millions of } \\
\text { heads: }\end{array}$ & & & & & \\
\hline & cattle & 8.5 & 8.4 & 8.4 & 8.3 & 8.1 \\
\hline & pigs & 15.6 & 17.6 & 18.4 & 19.8 & 20.8 \\
\hline & sheep and goats & 4.4 & 4.3 & 4.2 & 4.1 & 3.7 \\
\hline & poultry & 425 & 445 & 452 & 460 & 449 \\
\hline 3. & $\begin{array}{l}\text { Production of } \\
\text { agricultural products, } \\
\text { million tons. }\end{array}$ & & & & & \\
\hline & grain & 77.6 & 76.2 & 86.2 & 95.0 & 79.5 \\
\hline & sugar beet & 29.9 & 34.7 & 45.5 & 45.8 & 37.5 \\
\hline & oil seeds and fruits & 9.4 & 10.1 & 11.7 & 11.8 & 13.8 \\
\hline & potatoes & 3.8 & 4.7 & 4.2 & 4.2 & 4.3 \\
\hline & vegetables & 2.6 & 2.9 & 3.1 & 3.5 & 3.6 \\
\hline & $\begin{array}{l}\text { cattle and poultry for } \\
\text { slaughter in slaughter } \\
\text { weight }\end{array}$ & 6.6 & 7.1 & 7.5 & 8.0 & 8.4 \\
\hline & milk & 14.4 & 14.7 & 15.1 & 15.7 & 16.2 \\
\hline & eggs, billions & 32.6 & 33.4 & 34.5 & 35.9 & 36.2 \\
\hline & $\begin{array}{l}\text { wool in physical weight, } \\
\text { thousand t. }\end{array}$ & 10.5 & 9.5 & 9.3 & 9.0 & 10.0 \\
\hline
\end{tabular}

We believe that in order to activate innovative processes and modernization it is necessary to develop and implement a state innovation policy [9] on a systemic knowledge-intensive basis, the main areas of which should be:

- development and implementation of an innovative system in the agroindustrial complex;

- regulatory support for innovation and protection of intellectual property in agriculture;

- agricultural research;

- establishment and operation of information and advisory centers on agriculture and agricultural issues $[10,11]$;

- development of international cooperation and application of foreign experience in Russian agriculture [12];

- innovative personnel policy (training and promotion of highly qualified, practically trained professionals and managers); 
- increased investment, including public investment in agriculture [13];

- introduction of knowledge-intensive innovative projects into agricultural production $[14,15]$ and more.

Consistently addressing these and other areas, the state will undoubtedly be able to revive the pace of modernization of agricultural production and ensure the country's food security.

\section{Conclusions}

1. In the agricultural industry of the Russian Federation, there is a growing need for increased rate of modernization and innovation boosting the quantity and quality of agricultural products.

2. Innovative processes improving own efficiency and productivity should cover all areas and processes of agricultural production, from management and organizational issues to the processing, marketing and storage of agricultural products.

3. Innovative processes and modernization of agricultural production depend directly on governmental innovation policies in this sector of the economy, as the functioning of the agricultural industry ensures the food security of the Russian Federation and helps to contain the pace and influence of the global food crisis.

4. In today's environment, given the diminishing resources, the introduction of new technologies, digitalization, and automation of the agricultural industry will allow to maintain the level of production of agricultural products and improve their quality.

\section{References}

1. E.V. Kadomtseva, N.M. Osovin, Prospects for the development of the national system of agricultural counseling during the transition to a digital agricultural economy, NGEI Herald, 2 (93), 83 (2019)

2. I.P. Voiku, A.A. Efimova, E.V. Stepanova, Formation of a model of the innovation development system in the regional agroindustrial complex, Innovation, 9 (215), 102 (2016)

3. M.A. Yurevich, N.A. Ekimova, E.V. Balatsky, Digital transformation of the economic science, Information Society, 2, 39 (2020)

4. A.S. Chekunov, Technological modernization of agricultural production: state, forms, methods and avenues for support, VGUIT Herald, 81 (1), 373 (2019)

5. A.K. Subaeva, Problems of technical and technological modernization of Russian agriculture in modern conditions, Herald of the Moscow State Agricultural Engineering University, 3 (85), 37 (2018)

6. E.A. Letyagina, E.V. Dadayan, A.N. Storogeva, Features and modern approaches to the analysis of the financial condition of the debtor as a necessary element of the bankruptcy procedure of agricultural enterprises, In the collection: III International Scientific Conference: AGRITECHIII-2020: Agribusiness, Environmental Engineering and Biotechnologies, "IOP Conference Series: Earth and Environmental Science" Krasnoyarsk Science and Technology City Hall of the Russian Union of Scientific and Engineering Associations 22002 (2020)

7. T.G. Gurnovich, L.V. Popova, E.A. Ostapenko, Investment aspects of reproduction of the technology base of rural economic organizations on an innovative basis, ASU Herald, 2 (200), 73 (2017)

8. I.I. Glotova, E.P. Tomilina, Assessment of the impact of Russia joining the WTO on the investment activity of the regional agricultural economy, Regional Economy: Theory and Practice, 47 (422), 49 (2015)

9. M.S. Oborin, Main areas of agriculture modernization in modern Russia, Herald of Mari State University: Agricultural Sciences Economic Sciences Series, 4 (2, 14), 119 (2018)

10. T.S. Kravchenko, Influence of investments on the development of the investment potential of the AIC, Moscow Economic Journal, 2, 34 (2020)

11. E.V. Ivanova, Agricultural counseling in the system of innovative development of the agricultural sector of a northern region, Economic and Social Changes: Facts, Trends, Forecasts, 10 (2), 284 (2017)

12. A.I. Bogachev, Innovation in agriculture in Russia: current trends and challenges, NGEI Herald, 5 (96), 95 (2019)

13. I.M. Podkolzina, A.V. Pavlyuk, Facilitation of the sustainable development of the agricultural economy within the framework of an innovative approach, Problems of Economics and Legal Practice, 1, 23 (2018)

14. V.I. Kiryushin, Scientific and innovative provision of agricultural development priorities, Achievements in Science and Technology of the AIC, 33 (3), 6 (2019)

15. V.I. Kiryushin, Current problems and contradictions of agricultural development, Agriculture, 3, 3 (2019) 